\title{
Islamic-Based Research Methodology for Development Studies
}

\author{
Shahir Akram Hassan \\ \{shahirakram@usm.my\} \\ Centre of Islamic Development Management (ISDEV), University Sains Malaysia 11800 USM, Penang
}

\begin{abstract}
The Islamic-Based Research Methodology is defined as a method of research that combines theology and the teachings of 'aqli; the nazari knowledge and the naqli; and combines epistemology and Islamic tasawwur. Hence, what is Islamic-based research methodology? How Islamic research methodology can be used in development studies? This paper will answer previous questions through two objectives. First, to identify the Islamic-based research methodology. Second, to analyze the used of Islamicbased research methodology for development Studies. To achieve these objectives documentary research is used in data collection method the data will be analyses by using content analysis. The results of this study show that there is various Islamic study which can be developed as Islamic based research methodology in three main areas of Islamic research methodology which is research design, data collection method and data analysis method. All of these are found to be suitable for use in development studies.
\end{abstract}

Keywords: Social Sciences, Islamic-Based Research Methodology, Development Studies

\section{Introduction}

This paper aims to discuss how Islamic-based research methodology is used for development studies. The Islamic-based research methodology is a research methodology from the perspective of Islamic social sciences constructed on Islamic sciences such as aqidah, usul al-fiqh, qawa'id fiqhiyyah, extraction process of fatwa, hadith and those of Qur'anic based knowledge such as exegesis, tajwid and qiraat. The questions are; what is Islamic-based research methodology? How can Islamic-based research methodology be used in development studies?

This paper will answer the previous questions through two objectives. The first is to identify the Islamic-based research methodology. The second is to analyze the use of Islamicbased research methodology for the development studies. By using document analysis and content analysis, this paper will discuss at least four important aspects. First, the conventional research methodology. Second, the construction of Islamic-based research methodology. Third, the analysis of Islamic-based research methodology for the development studies. The fourth is to conclude.

\section{Research Methods}

The conventional research methodology refers to the regular research methods used in conducting research. A research methodology is commonly used in conducting research 
especially in research related to development studies. In most places, research related to development studies is categorized in social sciences research.

In conducting research related to Social Sciences, the major research methodology which currently used is the conventional research methodology. Research in the field of Social Sciences is considered unacceptable except in reference to standard research methods such as the works of [1-9]. These works are among the most recent references to research methods that describe ways of conducting research properly. [10] explain that research from the perspective of Social Sciences and Management is research conducted following the rules and conventions of science, which is through logic and systematic evaluation.

To ensure that a research is scientifically acceptable, numerous works have been published to assist in providing appropriate research methods for conducting such research, such as $[2,3,7-12]$ are international and national works such as the works of $[1,4-6,13]$.

These works contribute to the development of scientific and systematic research. All of them assist with at least three important components of the research methodology: research design, data collection method and analysis method. Some works provide complete assistance in conducting and writing such research $[2,4,6,7,11]$. However, some focus on specific aspects of research such as [3] and [13] that focus on quantitative data analysis. [9] focused on research involving case studies. There are also works written on separate fields such as [8] works in Behavioral and Social Sciences, [8] work in socioeconomic studies, [12] in education and [10] is a work of research methodology in business.

However, all of these works comprise three components of conducting research which are research design, data collection method and data analysis method. The research design is the framework and structure used to achieve the research objectives. The data collection method is the method used to collect data in conducting research. Proper data collection methods are essential to ensure that the results of the study correspond to the stated objectives. The data analysis method is the method used to analyze the data collected to achieve the purpose and objectives of the study.

In research, the research design is important as it will provide a pattern and determine the method of data collection to be used. The method of data collection needs to be clarified to give an idea of how the data sources in the study are derived. Studies that have the right data sources are believed to lead to an increased likelihood of producing accurate research results. It works similarly to the data analysis methods. With the right data analysis method, it leads to an excellent analysis in answering the research questions.

However, from a different perspective, [14] states that research methodology is often inappropriate for Islamic related research for three reasons. First, the philosophy and epistemology of conventional research methodology are very different from Islamic tasawwur and epistemology. Second, tools in conventional research are often insufficient to understand social reality; and thirdly, the complete adherence to some of the original concepts in conventional research methodology such as objectivity, scientific and anti-dogmatism, without any modifications, could affect the aqidah. This is also supported by [15-16] who argue that Western civilization separates religious knowledge and dogma. As such, research methods often reject the concept of monotheism (Islamic tasawwur) and do not accept revelation as a source of knowledge in epistemology [16]. Reason or faculty of intellect is the sole element considered in all things which assisted by the senses. This can be seen clearly when the question of human origin arises. Where humans come from, where humans are sent and where humans return [15]. When revelation is rejected, confusion will arise. Any answer that does not lead to Allah SWT, will lead to atheism. This is what [14] pointed out in which 
conventional methods of research can be harmful to aqidah. The cause is that it does not refer to Islamic philosophy and epistemology.

\section{The Construction Of Islamic-Based Research Methodology}

Based on the issues and arguments discussed in the previous section, the majority of Islamic thinkers such as [14, 17-22] who understand the problems of conventional research methodology call for the construction of Islamic-based research methodology

Therefore, there are efforts to develop a method of Islamic-based research that is a research method built based on previous Islamic knowledge. The Islamic-based research methodology is defined as a method of research that combines theology, evidence of 'aqli and naqli as well as the observed knowledge and makes Islamic epistemology and philosophy a key step in the process of researching Islam and Muslims [23].

However, the works of such thinkers as [14,17-19,21,24] discuss only on philosophical concerns in conducting research. To date, as [14] has put forth, there has not been much work that discusses the technical aspects of research, particularly the research design, data collection methods and data analysis methods. If anything, it is still very early and fragmented.

Some of those works that try to delve into the technical aspects of constructing Islamicbased research methodology are [23,25-32]

[29] and [25] attempted to develop the Islamic-based research methodology and integrate Islamic knowledge into research methods. However, as [14] has stated, [29] incorporates technical aspects taken from the West by arguing that it is a tool of science and does not contradict Islam without elaborating on the aspects of philosophy and epistemology. [25], however, gives his opinion on the issue of research in the social sciences from the Islamic point of view only. From a technical standpoint, he only mentions practical steps such as how to select a title, creating a writing schedule, how to select a reference, how to write a footnote and so on.

[27] also produced a work like [25] explaining practical steps but in the second part of his book, [27,33] lists the appropriate references by field in the study of Fiqh Islam such as references in Fiqh, comparative Fiqh, Usul Fiqh, Fiqh terminologies, rules in Fiqh and biography of Fiqh scholars.

This is in contrast to $[28,32]$ who tried to propose something new to the development of Islamic-based research methodology. [28] at the beginning of his writing criticized and described the negative effects of conventional research methods. What distinguishes him from other authors is that he lists seven general methods for Islamic-based research methodology. The seven general methods are, first, the requirement to set boundaries in Pure Science and Social Science. Second, the requirement to place revelation as one of the sources of reference and source of knowledge as well as social science. Third, the requirement to remain in the Islamic monotheistic sect. Fourth, the requirement to break free from any personal strife, the tendency of thought and ideology. Fifth, the requirement for commitment in theory. Sixth, the requirement to define what is constant and what is changing, and seventh, the requirement to overcome any personal and fixed interpretations comprehensively.

[32] came up with an attempt to delve deeper into the Islamic-based research methodology in the field of Social Sciences. He tries to bring several Islamic research techniques into textual analysis and linguistic texts such as text clarity, expression, structure, text terminology and discourse terminology, ta'wil and metaphorical languages, ta'lil, the settings of 'illah, ikhtilaf' and 'ijma'. Likewise, the third chapter brings together the methodology of logical knowledge which is used as an Islamic-based research methodology. 
He explains the definitions of knowledge, logic, concepts, and the rules of making definitions, statements, types of statements, categories, conditional statements, arguments of syllogism, confusion, induction and most of the methods of reasoning in logical science. [32] is the author with the most listed Islamic-based research methodologies but it still requires additional technical aspects that would meet the requirements of a research methodology and in terms of explanation.

In contrast to [32] who proposed and recognized logic as one of the methods for Islamicbased research,[15] began by criticizing logic in the view of Ibn Solah and Ibn Taymiyyah who forbade studying logic. However, he emphasized that there was a method which is very similar to logic before the arrival of the Arabs which is the method of the Usul Fiqh. The Usul Fiqh method has been indirectly present in the Fiqh of Muslims since the time of Ibn 'Abbas and Imam al-Syafi'i as the author of the science of Fiqh. Interestingly, [15] later established the method of scholars in four important areas of Social Science, namely psychology, morals, sociology and politics. All of these general methods address important issues in each of these areas. The method is based only on the Qur'an and the Hadith. For example in the field of psychology, he answers the basic questions of every human being. Where did humans come from? For what is a man created? And where do people go after death?

Besides, the work of [31] is seen as trying to provide a new dimension to Islamic-based research methodology. The title gives the book a comprehensive picture of the Islamic-based research methodology. He outlines research methodology from all disciplines in Islam starting with Tafsir, Islamic Philosophy, Islamic Theology, Tasawwuf, Fiqh, Politics, History and Islamic Education. However, the book briefly outlines the efforts and approaches of earlier scholars in the disciplines of Islamic science mentioned earlier.

In addition to the existing works, there is a comprehensive effort being undertaken by the Islamic Development Management Research Center (ISDEV), University of Science Malaysia to develop a widely accepted Islamic-based research methodology. This is evidenced by studies conducted by [20,26, 34-37] studies are among the examples of efforts to build Islamic-based research methodology from Islamic knowledge, though they appear to be studied separately. The separate here means that these studies only discuss some of the specific components of the three Islamic-based research methodology, namely research design, data collection method and data analysis method.

For the research design, [34] and [26] attempt to study what can form the research design based on existing knowledge in Islam. [26] proposes that algebra be applied in Islamic-based research. According to him, this algebra is a grouping of algebraic formulas created by an Islamic scholar named al-Khawarizmi. It is found to be useful in solving problems in Islamic calculations, especially in the estimation of inheritance. This study also found that algebra is well-versed in Islamic philosophy and epistemology and is suitable for Islamic-based research methodology. The study of [34] attempts to propose the application of the extraction process of fatwa in Islamic-based research methodology. Among his discussions are to apply the four extraction processes of fatwa which are taswir, takyif, ta'sil and al-hukm to formulate a research design based on the extraction process of fatwa especially if the study involved the law.

For data collection, at least two studies have been completed. But both are based on the method of collecting hadith. [36] suggested that the method of collecting Hadith was applied to the data collection method while conducting research related to Islam and Muslims and [20] in his study focused on the validity and reliability of data using the Naqd al-Hadith method. The study of the validity and reliability of data was then conducted by [20] by taking the simplicity and ability of data from the concept of qiraat mutawatir. 
For data analysis methods, at least the studies of [38] and [30] have been completed. [38] in his study attempts to apply the mantle of reasoning in Islamic-based research methods. There are at least five methods of reflexive reasoning that can be applied directly to the research that is, first, the method of describing something through 'alfaz, mafahum and masadaq. Second, the method of obtaining a comprehensive picture through ratio. Third, the method of defining according to logical knowledge. Fourth, the method of constructing true statements and propositions through tasdiq. Fifth, the method of evaluating true or false statements and propositions through taqabal and 'akas. [30] on the other hand, studies the use of dilalah as a method of analyzing data, especially for textual analysis. He discussed how to analyze texts in conducting research related to Islam using knowledge derived from the science of fiqh. Looking at it, both studies are trying to explore data analysis methods from existing Islamic knowledge.

[35] examines the methods of interpretation used by previous scholars and attempts to apply them in the context of the current Islamic-based research methodology, from the context of research design, data collection methods and data analysis methods. As a result, there are several methods of interpretation that are considered to be useful in the research design, data collection and data analysis methods. Among them are al-tahliliy techniques, ijmaliy techniques, al-muqaran techniques and al-mawduiy techniques. All four of these techniques have their purpose and research design, leading to their own data collection and data analysis methods per the disciplines of knowledge set by previous scholars.

Although the focus is on the three main components of the research which are the research design, the data collection method and the data analysis method, the philosophical stage of the study is not neglected. Most are trying to re-evaluate the major concepts in the research methodology that are common to Islamic perspectives. For example, [39] in his study of anti-dogmatism. [23] attempts to unravel the scientific concept in Islamic research based on the work of Islamic scientist Ibn al-Haytham through his book al-Manazir. He succeeded in finding the scientific concept of Ibn al-haytham in line with Islamic preference in the areas of epistemology, philosophy, analytical tools, ontology and goals. [40] then explores how to put value in Islamic-based research methodology. It is related to what extent the value is infused or to what extent free values are allowed or in between. Subsequently, [26] examines objectivity in Islamic-based research methodology with a focus on Al-Biruni in Kitab AlHind.

From previous studies, although it may be seen that efforts are being made to develop Islamic-based research methodology, it need not be limited to studies of Islam and Muslims. The Islamic-based research methodology is seen as contributing significantly to transdisciplinary studies. Among them are social sciences and development studies. Discussions on Islamic-based research methodology for development studies are as follows.

\section{Analysis Of Islamic-Based Research Methodology For Development Studies}

Development studies have been in the community since the beginning of human civilization. However, more specifically, development studies are based on the discussion of the existence of the poor in society and how society has changed over time. Scholars regularly discuss how to build a community. David Hume, Adam Smith, James Steuart and John Stuart Mill discuss economic growth, the distribution of wealth and the principles underlying public action [41]. Likewise after the Second World War, at the national level, there was a discussion 
of how to rebuild a country after the war. Therefore, the study of development is crucial and imperative and covers several disciplines of knowledge and across fields.

The same thing occurred to Muslims and Islamic countries. Studies and research on development need to be carried out. The question is, how the research methodology is used? As research development studies are conducted on Muslims and Islamic countries, research methods are also required to be using Islamic-based research methodology. There are at least four things that show how the Islamic-based research methodology can be used to research development studies.

First, in the development studies related to Islam, redefining the concepts used in each Islamic study is required. These concepts must be based on Islam. If the researcher overlooks this, the results of the study using definitions and concepts that are not in line with Islam will be similar to those conducted by non-Muslim researchers. To get a high-quality definition, logic suggests that something should be studied in depth before defining it using kulliyyat khams. Kulliyyat khams consist of five things namely nau', jins, fasl, 'aradh khas and 'aradh 'am [33, 42-44]

For example, [14,22,45] has written about wealth management and the search for the meaning of Islamic marketing. In drawing on wealth management, [45] looks at the origin of wealth management. Is it from Islam itself or traditional management? Interestingly, instead of applying the existing definition, he first discusses the Islamic view of wealth. Who needs to get wealthy? Then he discussed the objects placed under wealth management. After thoroughly understanding the rich and poor concepts of Islam, he then made the decision that he needed in searching the definition of rich and poor according to Islam.

In other words, the definitions made must be in line with Islam and the concepts of Islam itself. Once this is completed, only then the definition can be used to describe something related to Islam and Muslims. Besides, only then will the study be conducted on Islam and Muslims produce results that are compatible with Islam and Muslims.

Second, re-evaluate the conceptual framework or theoretical framework used from an Islamic perspective. Usually, in conducting research, one of the things to do is to highlight past research and literature review. Subsequently, a conceptual framework or theoretical framework will be developed. The development of this conceptual framework or theoretical framework is one of the most critical processes in conducting research and development studies are no exception. Not only is it important to determine the strength of research, but it also determines the accuracy of a concept or theory with Islam. If the conceptual framework or theoretical framework is correct, then the study strengthens Islam. On the other hand, if the conceptual framework or theoretical framework of a study is incompatible with Islam, methodology, research findings, the analysis of the study should be re-examined whether it reinforces Islam or it reinforces the concept or theory used.

For example, there are two commonly used theories for assessing consumer behavior, namely theory reasoned behavior (TRB) proposed by [46] before later being developed by [47] through theory planned behavior (TPB). These two theories have been used to test Muslim behavior especially in the areas of individual behavior [48]. Examples of studies on the concept of intention that have applied TRB and TPA are [49-53]. This shows that issues related to actions and behavior related to Islam and Muslims are also studied using this theoretical framework. If these two theories are not re-evaluated, the methods of measuring and evaluating them are not following Islamic requirements or are incompatible with the nature of Muslims, thus suggesting inaccurate findings.

Third, after looking at the conceptual or theoretical framework of a research-based on Islam, the development of research instruments in development studies should also be of 
particular importance in the field of measurement. Measurement in research is a way of associating abstract concepts with empirical direction [4]. It is a method of classifying abstract concepts into specific clues that can be analyzed and described accurately. In the research, each abstract concept will be expressed using one specific, measurable direction. These concepts are called variables. Variables are those that can be replaced by numbers that represent different values [2]. According to conventional research practice, variables are usually measured in four scales, namely, nominal, ordinal, interval and ratio. How is Islamicbased measurement? Does Islam have its method of measurement? Given these aspects of measurement, it also raises the question of whether the institution is best suited to study development related to Islam and Muslims in particular and Islamic assessment of development studies in general.

Fourth, the method of data analysis is based on Islam. Studies on Islam and Muslims need to be made from the Naqli and the 'Aqli arguments which include things that are visible and invisible. In Islam, even though data does not have empirical evidence, but if it is mentioned in the Qur'an and al-Sunnah, it is considered as reliable data, even reaching the certainty level. For example, through revelation, some things do not require observation or empirical evidence. It is enough to do exactly what the revelation suggests.

In research on Islam, in addition to studying tangible matters, Islam also considers supernatural things. Understanding the supernatural will lead to a holistic understanding from the Islamic point of view. It makes the data obtained based on what you see. For example, the research results in economics. If such a study focused only on logical and empirical matters, the results would likely be materialistic. At the same time, because it cannot be scientifically proven, spiritual needs cannot be included. In this regard, society will be bribed with artificial needs that will not help to understand humanity holistically [54].

\section{Conclusion}

From the above discussion, we can conclude four things. First, development studies are cross-disciplinary science that includes Islamic science and Muslims related knowledge. Second, there is a concerted effort to develop a method of research based on Islamic knowledge called the Islamic-based research methodology. Third, there is a need to use the Islamic-based research methodology for development studies. Fourth, there are at least four things; redefining the concepts used in each Islamic study; re-evaluate the conceptual framework or theoretical framework used from an Islamic perspective; the development of research instruments in development studies based on Islam; and, Islamic-based data analysis methods.

Acknowledgements. This paper is a part of research findings of a study entitled Research Design in Islamic-Based Research Methods and was financed by Research University Individual Grant (RUI), Universiti Sains Malaysia [(RUI)1001/CISDEV/8016060].

\section{References}

[1] A. M. Ayob, Kaedah penyelidikan sosioekonomi, Edisi Keti. Kuala Lumpur: Dewan Bahasa dan Pustaka, Kementerian Pendidikan Malaysia, 2005.

[2] N. Blaikie and J. Priest, Designing social research: The logic of anticipation. John Wiley \& Sons, 2019.

[3] N. Blaikie, Analyzing quantitative data: From description to explanation. Sage, 2003. 
[4] Y. P. Chua, Kaedah dan statistik penyelidikan: kaedah penyelidikan. Mcgraw-Hill Education, 2011.

[5] Z. Mahmud, Handbook of Research Methodology: A simplified version. UPENA, 2008.

[6] S. Marican, Kaedah penyelidikan sains sosial. Prentice Hall/Pearson Malaysia, 2005.

[7] N. W Lawrence, "Social Research Methods: Qualitative and Quantitative Approaches." Pearson Education Limited, 2014.

[8] B. L. Weathington, C. J. L. Cunningham, and D. J. Pittenger, Research methods for the behavioral and social sciences. John Wiley \& Sons, 2010.

[9] R. K. Yin, Case Study Research: Design and Methods, 4th editio., vol. 5. Thousand Oaks, CA, USA: Sage Publications, 2009.

[10] G. W. Ticehurst and A. J. Veal, Business research methods: A managerial approach. Addison Wesley Longman, 2000.

[11] E. Adler and R. Clark, How it's done: An invitation to social research. Cengage Learning, 2007.

[12] B. W. Tuckman, "Conducting Educational Research Fith Edition," New York Harcount Brace Coll. Puplisher, 1999.

[13] M. Ismail, Kaedah penyelidikan kuantitatif dalam pendidikan. Dewan Bahasa dan Pustaka, 2011.

[14] M. S. Salleh, Kaedah penyelidikan berteraskan Islam: Keperluan, kedudukan dan hala tuju. 2008.

[15] M. Hilmi, Method of Research in Humanities Between Muslim Scholars and Western Philosophers, First Edit. Lebanon: Dar Al-Kotob Al-Ilmiyah, 2005.

[16] N. Sulaiman, "Sains, Falsafah, dan Islam," Bangi Penerbit UKM [Universiti Kebangs. Malaysia], 1993.

[17] S. Z. Abedin, "Problems of Islamic Research in Muslim Philosophy," Muhammad Mumtaz Ali. Conceptual and Methodological Issues in Islamic Research: A Few Milestones. Kuala Lumpur: Dewan Bahasa dan Pustaka. 1995.

[18] F. R. Faridi, "The need for an Islamic theory and methodology of history," Kuala Lumpur Synerg. B. Int., 1999.

[19] J. Farooqui, "Islamic Perspective of Methododology in Social Phenomenal Context," Mohammad Muqim Res. Methodol. Islam. Perspect. Kuala Lumpur. S, pp. 215-241, 1999.

[20] N. H. Ismail, "Kaedah Naqd Hadith Sebagai Kaedah Penentu Kesahan Data Bagi Penyelidikan Berkaitan Islam," Universiti Sains Malaysia, 2015.

[21] R. A. A. Rahim, "Ke Arah Penyediaan Kaedah Penyelidikan Hukum Islam Terkini: Satu Pengenalan," J. Syariah, vol. 10, no. 1, pp. 1-24, 2002.

[22] M. S. Salleh, "Rethinking wealth management: An Islamic preliminary view," Int. J. Bus. Soc. Sci., vol. 3, no. 13, 2012.

[23] M. S. Alias, "Konsep Saintifik dalam Kaedah Penyelidikan Berteraskan Islam: Analisis Pemikiran Ibn al-Haytham," Universiti Sains Malaysia, Pulau Pinang, Malaysia, 2014.

[24] M. Rafiuddin, "Problems of Research in Islamic revealed: Revealed Knowledge (Islamic Studies).” Kuala Lumpur: Dewan Bahasa dan Pustaka, 1996.

[25] Farid al-'Ansari, "Abjadiyyat al-Bahth Fi 'Ulum al-Shar'iyyah." Dar al-Hamid, Amman, p. 208, 2008.

[26] N. I. Mat Nawi, “Aplikasi Algebra Dalam Kaedah Penyelidikan Berteraskan Islam," Universiti Sains Malaysia, 2012.

[27] Abd al-Wahhab Ibrahim, "Kitabat al-Bahth al-'Ilmi Wa Masadir al-Dirasat alFiqhiyyah.” Dar al-Shuruq, Jeddah, 1993. 
[28] M. M. Amziyan, "Manhaj al-Bahs al-Ijtimaie Baina al-Wad'iyyah Wa al-Mi'yariyyah." Virginia: al-Ma'had al-'Alami al-Fikr al-Islami, 1991.

[29] A. S. Long, Pengenalan Metodologi Penyelidikan Pengajian Islam. Jabatan Usuluddin dan Falsafah, Fakulti Pengajian Islam, Universiti ..., 2011.

[30] M. S. B. M. Miswan, Aplikasi Dilalat dalam kaedah penyelidikan berteraskan islam (KPI). 2013.

[31] A. Nata, "Metodologi Studi Islam Jakarta: Raja Grafindo Persada," 2004.

[32] L. Safi, The foundation of knowledge: A Comparative study in Islamic and western methods of inquiry. International Institute of Islamic Thought (IIIT), 2014.

[33] A. al-W. Ibrahim, "Kitabat al-Bahth al-'Ilmi Wa Masadir al-Dirasat al-Fiqhiyyah." Dar al-Shuruq, Jeddah, 1993.

[34] W. M. K. F. Wan Khairuldin, "Aplikasi proses penfatwaan dalam kaedah penyelidikan berteraskan Islam," Universiti Sains Malaysia, 2014.

[35] A. H. Embong and M. S. Hanapi, "The Application Methods of the Holy Quran's Interpretations in Islamic-Related Research," Int. J. Acad. Res. Bus. Soc. Sci., vol. 7, no. 2, pp. 521-535, 2017.

[36] S. A. Hassan, "Kaedah Pengumpulan Hadith: Satu Kaedah Pengumpulan Data," Disertasi Ijazah Sarj. Sains Kemasyarakatan yang diserahkan Kpd. Pus. Kaji. Pengur. Pembang. Islam. Pus. Pengaj. Sains Kemasyarakatan, Univ. Sains Malaysia. Tidak diterbitkan, 2010.

[37] N. S. Ab Aziz, "Aplikasi konsep mutawatir dalam imu qiraat sebagai kaedah penentu kesahan dan kebolehpercaaan data dalam kaedah penyelidikan berteraskan Islam." 2018.

[38] S. A. Hassan, "Aplikasi kaedah penaakulan mantik dalam penyelidikan berkaitan Islam," Universiti Sains Malaysia, 2014.

[39] A. Abdullah, "Kedudukan dogma Islam dalam kaedah penyelidikan berteraskan islam," Utusan Publications \& Distributors Sdn Bhd, 2014.

[40] M. S. Alias, "Bebas Nilai dalam Penyelidikan saintifik: Kajian dari perspektif Perkaedahan Penyelidikan Berteraskan Islam," Center for Islamic Development Management Studies, Universiti Sains Malaysia, Pulau Pinang, Malaysia, 2016.

[41] B. Currie-Alder, "The state of development studies: origins, evolution and prospects," Can. J. Dev. Stud. Can. d'études du développement, vol. 37, no. 1, pp. 5-26, 2016.

[42] M. Al-Syanqiti, "Al-dhaw al-musyriq 'ala sullam al-mantiq," Beirut: Dar al-Kutub alIlmiyyah. 2007.

[43] A. Damanhuri, “'Idah al-Mubham Fi al-Ma'ani al-Sullam.” Maktabat al-Ma'arif, Beirut, 1999.

[44] H. S. Sambas and C. Cuanda, Mantik: kaidah berpikir Islami. PT Remaja Rosdakarya, 2012.

[45] M. S. Salleh, "Islamic Marketing: In Search Of Its Meaning," Konf. Int. di Alam Melayu, 2012.

[46] M. Fishbein and I. Ajzen, "Intention and Behavior: An introduction to theory and research." Addison-Wesley, Reading, MA, 1975.

[47] I. Ajzen, Attitudes, personality, and behavior. McGraw-Hill Education (UK), 2005.

[48] A. A. Adnan, "Gelagat pengguna Islam: Satu disiplin atau sub-disiplin?," J. Pengur., vol. 35, pp. 139-149, 2012.

[49] Z. Bidin, K. M. Idris, M. Shamsudin, and Faridahwati, "Predicting Compliance Intention on Zakah on Employ- ment Income in Malaysia: An Application of Reasoned Action Theory," J. Pengur., vol. 28, pp. 85-102, 2009. 
[50] M. Md Husin and A. Ab Rahman, "Predicting intention to participate in family takaful scheme using decomposed theory of planned behaviour," Int. J. Soc. Econ., vol. 43, no. 12, pp. 1351-1366, 2016.

[51] M. Md Husin and A. Ab Rahman, "Do Muslims intend to participate in Islamic insurance? Analysis from theory of planned behaviour," J. Islam. Account. Bus. Res., vol. 7, no. 1, pp. 42-58, 2016.

[52] M. Md Husin and A. Ab Rahman, "What drives consumers to participate into family takaful schemes? A literature review," J. Islam. Mark., vol. 4, no. 3, pp. 264-280, 2013.

[53] R. A. J. Saad, Z. Bidin, K. M. Idris, and M. H. Md Hussain, "Faktor-faktor yang mempengaruhi Gelagat Kepatuhan Zakat Perniagaan,” J. Pengur., vol. 30, pp. 49-61, 2010.

[54] A. Unal, Islamic Perspectives on Science: Knowledge and Responsibility. Tughra Books, 2007. 